\title{
The Existence of Constitutional Court Decisions in the Norms System in Indonesia
}

\author{
Amien Ru'ati ${ }^{1}$, SEM Nirahua ${ }^{2}$, J. Tjiptabudy ${ }^{2}$, H. Salmon ${ }^{2}$ \\ ${ }^{I}$ Graduate Student PhD, Study Program : Science Of Law. Pattimura University, Ambon, Indonesia \\ ${ }^{2}$ Faculty Of Law. Pattimura University, Ambon, Indonesia
}

DOI: 10.29322/IJSRP.11.12.2021.p12016

http://dx.doi.org/10.29322/IJSRP.11.12.2021.p12016

\begin{abstract}
The Constitutional Court is a judicial institution established based on the orders of the 1945 Constitution which has the constitutional authority to conduct judicial review of the 1945 Constitution whose decisions are final and binding. However, in the implementation of the examination, many decisions of the Constitutional Court are not implemented by other state institutions which have the duty to follow up and implement the decisions of the Constitutional Court so that legally it can interfere with the existence and strength of the implementation of the Constitutional Court's decisions. The type of research used in this paper is normative juridical research. The decision of the Constitutional Court is part of the norm system (hierarchy of laws and regulations) and in Indonesia, its position is the same as the laws and government regulations and is used as a source of law by the DPR and the Government in forming new laws related to the decisions of the Constitutional Court.
\end{abstract}

Keywords: hierarchy, laws, decisions of the constitutional court.

\section{INTRODUCTION}

The existence of the Constitutional Court Decision is constrained in its implementation due to political interests by the legislators, because the Constitutional Court Decision is not immediately implemented by the Government and/or state organs and government organs that are related to the Constitutional Court Decision. Therefore, in the practice of administering the state and government based on the Constitutional Court Decisions, there is no firmness related to the implementation of the Constitutional Court Decisions by the DPR or the Government so that the Constitutional Court Decisions become part of the source of laws and regulations and must be implemented.

A decision that changes the meaning of the formulation of an article in the 1945 Constitution of the Republic of Indonesia can be called a judicial interpretation which is formally in the form of a binding Constitutional Court Judge's Decision (erga omnes). In the Indonesian constitutional legal norm system, decisions like this are located as one of the sources of formal law called Constitutional Jurisprudence. Materially, the decision is a Judicial interpretation which is one of the ways to amend the 1945 Constitution of the Republic of Indonesia (materially), therefore it is equivalent to the 1945 Constitution of the Republic of Indonesia / Amendments to the Constitution of the Republic of Indonesia. Year 1945 and can be categorized as a constitution in a broad sense; in the legal sense; and in a material sense. Meanwhile, decisions that do not change the meaning/meaning of the formulation of articles in the 1945 Constitution of the Republic of Indonesia, are only complementary and only interpretations (explanation), so that they are not binding (as the Constitution) as in the Constitutional Court Decision which changes the meaning/meaning Article formulation in the 1945 Constitution of the Republic of Indonesia.

Based on the understanding of the interpretation above, it can be related to Decision No. 108/PUU-XI/2013, namely the petitioner's request for an interpretation of the constitution by the Constitutional Court (which according to the Constitutional Court is a fatwa category). against the 1945 Constitution of the Republic of Indonesia. This is due to the interpretation of the articles related to the general election, and the general election of president and vice president may cause a change in the actual meaning of the intent and purpose of the article in the 1945 Constitution of the Republic of Indonesia.

Constitutional Court decisions often surprise many people. Although this institution is still new

(The data has registered 69 cases of judicial review of the constitution at the Constitutional Court of the Republic of Indonesia. Of all these cases, 63 cases (91.3\%) have been decided by the Court and of the 63 cases decided, there are 20 cases (31.8\%) which were granted by the Court. So there are 20 laws that have been stated by the Constitutional Court, both part and all of their articles are declared to have no binding legal force), many of its decisions can be said to be very bold and cause debate among legal experts and politicians. Some of the decisions that lead to debate the pros and cons among others, the abolition of a ban on voting rights for ex-members of the Movement 30S/PKI (Decision on Case No. 011-017/PUU-I/2003), states that it has no binding legal force as a whole the electricity law, states that it does not have legal force to bind the provisions of Article 50 of Law Number 24 of 2003 concerning the Constitutional Court which means expanding the authority of the Constitutional Court itself, stating that it has no legal force binding several Articles of Law Number 22 of 2001 concerning Oil and Gas and many others.

These developments have created a debate about the position of the Constitutional Court in the constitutional format of the Republic of Indonesia. The Constitutional Court seems to want to monitor and "execute" its own implementation of its decision so that it is respected. However, from the decisions of the Constitutional Court that have been issued by this institution, one of the decisions that have not been executed by the House of Representatives until now is the decision issued on the lawsuit 
for the Judicial Review of the MD3 Law which is considered to have reduced the authority of the DPD so that it is not in accordance with the breath of the Act. The 1945 Constitution of the Republic of Indonesia. The lawsuit to the Constitutional Court based on Case Number 92/PUU-X/2012 was decided in February 2013, with the decision granting the petition in part, so that this has shifted the legislative function of the Regional Representative Council, so that The decision of the Constitutional Court that is not implemented will have an impact on the existence of a state institution and/or government institution and the existing norm system of the country, including the Unitary State of the Republic of Indonesia.

\section{RESEARCH METHOD}

Research is a systematic, directed and purposeful scientific activity. For this reason, the data or information collected must be relevant to the problem at hand. This means that the data is related, relevant and accurate (Kartini Kartono in Marzuki). A method is a way of working or working procedures to be able to understand the object that is the target of the science concerned. The method is a guideline for how a scientist learns and understands the steps he faces. The type of research used in this paper is normative juridical research. Normative juridical research is a legal research method that is carried out by examining library materials or mere secondary materials.

\section{RESULTS AND DISCUSSION}

\section{The Existence of Constitutional Court Decisions in the Norms System in Indonesia}

\section{Legal Consequences of the Constitutional Court Decision}

The question that is often asked of us is how the execution of the Constitutional Court's decision is carried out, what if the government does not comply with the Constitutional Court's decision while still enforcing a law that has been declared to have no binding force. The Constitutional Court's decisions, most of which, especially in the judicial review of laws, are declaratoir constituief, meaning that the Constitutional Court's decision creates or eliminates a new legal situation or establishes a new law as a negative legislator called Hans Kalsen through a statement. Such a declaratory nature does not require an apparatus to carry out the decision of the Constitutional Court judge.

Likewise, the Constitutional Court's decision which contains an order stating that part of the law or certain articles/paragraphs do not have binding legal force, the decision has had binding force since it was announced in a trial open to the public. (Maruar Siahaan, 2005) However, as a condition for public knowledge, such decision being announced in the State Gazette within a period of no later than 30 (thirty) days after the decision is pronounced has the following conditions:

a. If the government or other state institutions do not comply with the decision and in fact still enforce a law that has been declared by the Constitutional Court to have no binding legal force, it is an action whose supervision is in the legal mechanism and state administration itself. Acts committed on the basis of a law that has been declared null and void and has no binding legal force is an act against the law, if the legal consequences that occur are in the form of financial losses, the state apparatus or state institution will bear the legal consequences that can be personal ( personal liability) for compensate for the damages claimed through ordinary courts which can be enforced by force. However, from a constitutional point of view, such an unlawful act, if carried out by the government or the President, may trigger the political process in the DPR and may lead to the President being no longer eligible to become President due to reasons stated in the Constitution.(Maruar Siahaan, 2005)

b. Since the decision of the Constitutional Court is pronounced before a court, it is open to the public, it can have 3 (three) powers, namely (1) binding power,(Maruar Siahaan, 2005) (2) the power of proof, and (3) the power of execution. This type of decision power is known in the theory of civil procedural law in general and this can also be applied in the procedural law of the Constitutional Court.

c. In particular, for cases of disputes between state institutions that obtained their authority from the 1945 Constitution of the Republic of Indonesia, the situation is slightly different. On the one hand, the decision on a dispute between such institutions actually has a condemnatory aspect, although it is not explicitly stated in the law. Strictly speaking, in such a dispute, there are two parties facing each other, namely the applicant and the respondent who both consider that they have legal authority. An interim decision of the Constitutional Court issued before the final decision is taken may order that the respondent as a state institution does not exercise the authority in dispute before the subject matter is decided. The contents of such a decision are punishable by an interim decision and it is stated that the respondent as a state institution is not entitled to exercise the authority disputed by the two parties concerned and is obliged to comply with the decision. However, in the event that the respondent does not implement the decision, it is clear by law that the applicant as a party justified by the Constitutional Court has the right to request to implement the decision (H. Abdul Latief et al 2009).

The Constitutional Court as a negative legislator, may grant the request of the respondent or reject it. However, there is a possibility that the application will not be accepted because it does not meet the required formal requirements. The Constitutional Court's decision nullifies a legal situation or creates certain rights or authorities. In other words, the decision will have certain consequences that affect a legal situation and/or authority. This means that the Constitutional Court judge's decision which states a law is contrary to the Constitution and has no binding legal force, may not apply retroactively. The legal 
consequences arising from the decision are calculated from the time the decision is pronounced in a trial open to the public. Therefore, the legal consequences arising from the enactment of a law from the time it is promulgated until a decision is pronounced stating the law does not have binding legal force, remains valid and binding. There are 2 (two) decisions of the Constitutional Court that can be used as a reference for studies on the legal consequences of decisions that declare the cancellation of a law. The first is case number 013/PUU-1/2003 which was decided on July 22, 2004 regarding the Judicial Review of Law Number 16 of 2002 concerning the Enforcement of Law Number 15 of 2003 concerning the Eradication of Criminal Acts of Terrorism retroactively for the Bali bombing incident, the second decision is case number $018 / \mathrm{PUU}-1 / 2003$ concerning the review of Law Number 45 of 1999 concerning the establishment of the Province of West Irian Jaya.(H. Abdul Latief et al 2009).

\section{The decision of the Constitutional Court is related to the Norms System in Indonesia.}

The decision of the Constitutional Court is final and binding ( final and bending ) since it is pronounced or read out in a plenary session which is open to the public. Therefore, the role of the publishing media and official announcements is very important. In this connection, it is recognized that there are 2 (two) kinds of publication and announcement media, namely (i) State Gazette, (ii) Supplement to the State Gazette, (iii) State Gazette, (iv) Supplement to State Gazette, (v) Regional Gazette and ( vi) Regional News.

The Constitutional Court's decisions are also required to be published in the State Gazette. However, the effective time for the Constitutional Court's decision to take effect is from the time it has been pronounced or read out in a plenary session open to the public. Supposedly, the distinction between the State Gazette and the State Gazette, and similarly between the Regional Gazette and the Regional Gazette, should not be related to the hierarchy of statutory regulations, but to its function as a media of promulgation or media of announcement. Because all statutory documents should be promulgated in the state gazette or regional gazette according to the level. However, the announcement media are state news and regional news according to their respective levels (H. Abdul Latief et al 2009).

In connection with the decision Number 92/PUU-X/2012 which has restored the authority of the Regional Representatives Council (DPD) which was previously reduced by Law no. 27 of 2009 concerning the MPR, DPR, DPD, and DPRD (MD3) and Law no. 12 of 2011 concerning the Establishment of Legislation (P3). Of the several points of the lawsuit filed by the DPD, 4 (points) of which are the essence of the existence and identity of the DPD as a state institution that needs to be reenforced as mandated by the 1945 Constitution, the decision is non-self implementing or waiting for its enactment by lawmakers in revise or assist the new law relating to the Constitutional Court's decision on the law, but in forming a new law by the legislators between the DPR and the government relating to the Constitutional Court's decision regarding the authority of the DPD which is at the level of the DPR and the government in forming a law, this becomes a legal issue that needs to be addressed. It is very important in our country's legal system, and this problem greatly affects the existence of the Constitutional Court itself as a judicial institution that is granted judicial review authority by law.

Whereas related to the problem above is related to the position or existence of the Constitutional Court's decision in the norm system in Indonesia (the hierarchy of laws and regulations), so there is no need to wait for it to be implemented or executed by other state institutions. much concern is the hierarchy of legal norms and chains of validity that make up the legal pyramid (stufentheorie). One of the figures who developed this theory was a student of Hans Kelsen, namely Hans Nawiasky. Nawiaky's theory is called theorie von stufenufbau der rechtsordnung. The arrangement of norms according to the theory is:

1. Fundamental norms of the country

2. Basic rules of the country

3. Formal laws, and

4. Implementing regulations and autonomous regulations (Hans Kalsen)

Staats fundamental norm is the norm which is the basis for the formation of the constitution or the Basic Law (staats verfassung) of a country. The legal position of a Staats fundamental norm is a condition for the enactment of a constitution. Staats fundamental norms exist before the constitution of a country. According to Nawiasky, the highest norm which Kelsen calls the basic norm in a country should not be called a staats grund norm but rather a staats fundamental norm, or state fundamental norm. Grund norms basically do not change, while the highest norms change, for example by means of a coup or revolution. Based on the Nawiasky theory, we can boasts - dingkannya with Kelsen's theory and apply it to the structure of the rule of law in Indonesia. Attamimi shows the hierarchical structure of the Indonesian legal system using Nawiasky's theory. Based on this theory, the structure of the Indonesian legal system is : (Jimly Asshiddiqie, M Ali Safa'at, 2006). Staats fundamental norm : Pancasila (Preamble of the 1945 Constitution).

1. Staats grund gesetz : Body of the 1945 Constitution, Decree of the MPR, and the Constitutional Convention.

2. Formell gesetz: Act.

3. Verordnung en Autonome Satzung : Hierarchically starting from Government Regulations to Decrees of Governors, Regents or Mayors.

Pancasila is seen as a legal ideal (rechtsidee) which is the driver. This requires that the formation of positive law is to achieve the ideas contained in Pancasila, and can be used to test positive law. With the stipulation of Pancasila as the Staats fundamental norm, the formation of law, its application, and its implementation cannot be separated from what is stated in Pancasila. Kelsen discusses the validity of legal norms by describing them as a chain of validity that culminates in a state constitution. If you ask why the constitution is valid, maybe you can point to the old constitution. It eventually reaches several constitutions up to the first constitution established by an individual or some kind of assembly. 
The validity of the first constitution is the final presupposition, the final postulate, on which the validity of all norms in the legal order depends. The document which is the first form of constitution is a real constitution, a binding norm, only in the condition that it is presupposed as valid. This presupposition is called the transcendental-logical presupposition .

All legal norms belong to the same legal order because their validity can be traced back, directly or indirectly, to the first constitution. That the first constitution is a binding legal norm is something that is prepositioned, and the formulation of these prepositions is the basic norm of this legal system. Basic norms are not made in legal procedures by law-making organs. This norm is valid not because it is made by means of legal action, but is valid because it is presupposed to be valid, and is presupposed to be valid because without this presupposition no human action can be interpreted as law, especially the norms of lawmakers.

This writing relates to the theory of Hans Kalsen and Hans Nawiasky in the field of law in Indonesia. As well as legal principles or principles which are the source of values and sources of norms for the formation of law and its hierarchy such as the 1945 Constitution of the Republic of Indonesia, Decrees of the People's Consultative Assembly, Laws, Laws/Government Regulations in Lieu of Laws, Government Regulations , Presidential Regulations, Provincial Government Regulations, and Regency/City Government Regulations, and so on. We can see this from the formulation of Article 7 of Law Number 12 of 2011 concerning the Establishment of Legislation.

Since the reformation, the order or hierarchy of laws and regulations has been rolled out which is usually the object of judicial review cases. Without knowledge of this theory, especially for competent institutions or organs, it can have bad consequences for its implementation. In the discourse of legal science, one of the genres of jurisprudence whose exponents mostly focus their studies on the hierarchy of legal norms is the legal positivism school. Hans Kalsen as one of the exponents of the genre of legal positivism instructs a model of the stufenbau des recht or the hierarchy of norms which is used as a theoretical reference by many countries in the construction of their legislative order. Although there are some thinkers who instruct the hierarchy of laws and regulations, but with different models or elements.

The exploration of Hans Kalsen's thoughts regarding the ab initio hierarchy of laws and regulations must be in the context of legal positivism or the hierarchy of norms Hans Kalsen is inherent in legal positivism legal reasoning. Hans Kalsen qualifies law as something purely formal. So, the legal system is a system of norms, the norm system is a tiered arrangement (hierarchy) and each norm is sourced from the norms above it, which form it or which provide and determine its validation and become the source for the norms below it. The apex of the hierarchy is a basic norm, namely the constitution. These basic norms are the highest basis for the validity of the entire legal system. The constitution referred to here is a constitution in a material sense, not a formal one.

The characteristics of the correlation between one norm and another in the hierarchical legal system can be understood through the description given by Hans Kalsen as follows: (Sri Soemantri,1987).

"The relation between the norm regulation the creation of another norm and this other norm may be presented as a relationship of super and sub-ordination, which is a spatial figure of speech. The norm determining the creation of another norm is the superior, the norm created according to this regulation, the inferior norm. the legal order, especially the legal order the personification of which is State, is therefore not a system of norms coordinated to each other, standing, so to speak, side by side on the same level, but a hierarchy of different levels of norms"

The stufenbaut des recht theory or the hierarchy of norms introduced by Hans Kalsen above can be interpreted as follows: 1) lower laws and regulations must have a legal basis or validation from a higher legislation. 2) the content or content of lower laws and regulations must not deviate or conflict with higher laws and regulations.

Regarding the substance of basic norms, Hans Kalsen distinguishes two types of norms or system of norms. Both are the static system of norms and the dynamic system of norms. The static norm system is a system that sees a norm in terms of the content or material of the norm itself. The content shows proven quality which directly guarantees its validity. Meanwhile, the dynamic norm system is a system that sees a norm whose formation is in accordance with the procedures determined by the constitution. In other words, the norm in the perspective of the dynamic norm system is the norm that was born by the authorized party to form the norm, of course, the norm is sourced from a higher norm. The authority is a delegation. Norms that make up power are delegated from one authority to another. The first authority is a higher authority, the second authority is a lower authority.

It seems that from the concept of the dynamic norm system constructed by Hans Kalsen above, it shows that the state organs that have the authority to form laws can be traced to their validity through a hierarchical institutional relationship. This concept can be understood as a consequence of the hierarchical character of the formation of legal norms. The hierarchy according to the perspective of a dynamic norm system is of course adapted to the institutional or state structure adopted by a country as regulated in its constitution.

In addition, the two concepts of legal norms in the perspective of a system of static norms and dynamic norms can be a guide to understanding that a norm can not only be seen or understood in terms of the validity of its content, it can also be seen or understood in terms of basic validity and the procedure for its formation and if there is material validity. the load and the nextlower or delegated norm-forming organ. More specifically, neither the material aspect of the content nor the aspect of the organs that make up a norm must not conflict with the above norm that determines it.

Associated with or discrepancies between a norm with other norms of different levels can be understood from the following statement by Hans Kalsen(Sri Soemantri,1987).

"There can, therefore, never exist any absolute guarantee that the lower norm corresponds to the higher norm. The possibility that the lower norm does not respond to the higher norm which determines the former's creation and content, especially that the lower norm has another content than the one prescribed by the higher norm, is not or all excluded. But as soon as the case has become a res judicate, the opinion that the individual norm of the decision does 
not correspond to the general norm which has to be applied by it, is without juristic importance. The law-applting organ has either, authorized by the legal order, created new subtative law. Or it has, according to its own assertion, applied preexisting subtative law. In the latter case, the assertion of the court of last resort is decisive."

Hans Kalsen's statement above shows that there is no guarantee that the lower norm is always in accordance with the higher norm that determines and the material content of the lower norm. However, according to the construction of the legal system, the determination of the conflict of norms is left to the competent authority.

Hans Kalsen said the competent organ was the court. The court organ is given the right to give a final decision on the case and its decision makes the case res judikata. More, Hans Kalsen (Sri Soemantri,1987) postulated that the nature of the final decision made by the competent authority is constitutive, not declarative. So, a decision that cancels a norm for certain reasons on the legal norm is null ab initio. Such cancellation is a cancellation with retroactive force.

From the paradigm constructed by Hans Kalsen above, in the event of a conflict of norms, it also shows that it requires the formation of an organ that determines the constitutionality or legality of a norm in other words, there must be an institutionalization of judicial review. Regarding the cancellation or nullity of a norm, it can be understood more clearly from Hans Kalsen's postulation as he states the following: (Anan Jamal,2009).

"The general principle which is at the basis of this view may be formulated in the following may: a legal norm is always valid. It cannot be nul, but iot can be annulled.There are, however,different degres of annulability. order may authorizet a special organ to declare a norm nul,that means, to annul the norm with retroactive force,so that the legal effects,previously produced by the norm,may be absolished.This is usually-but not correctly-characterized by the statement that the norm was avoid ab initio or has been declared nul and avoid. The declaration in question has, however, not a declaratory but a constitutive character: Without this declaration of the competent organ the norm cannot be considered to be avoid."

In principle, every legal norm is always valid, not null, but it can be canceled by a competent institution or organ for certain reasons according to the legal system. Consequently, a legal norm must always be considered valid until it is canceled when a competent institution decides to do so through a judicial review or if the legal norm is a law, then it is usually canceled by another law according to the principle of law. Lex posterior derogate priori or with desuetude. The description above can be used as a guide to understand the mosaic of Hans Kalsen's legal thinking with the Stufenbau des recht theory or the hierarchy of norms with legal positicism reasoning (Anan Jamal.2009).

Hierarchically, the Constitutional Court's decisions are not included in Law Number 12 of 2011, Article 9 of Law Number 12 of 2011 which regulates the review of the Act against the Basic Law (constitutional review) and the review of legislation under the Law on Law (judicial review). Such as Article 7 Paragraph (1) of Law Number 12 of 2011 , then Article 8 of Law Number 12 of 2011 which states the existence of other regulations other than those stated in Article 7 paragraph (1). These regulations are regulations issued by the MPR, the House of Representatives, the Regional Representatives Council, the Supreme Court, the Constitutional Court, the Supreme Audit Agency, the Judicial Commission, Bank Indonesia, the Minister, agency, institution, or a commission of the same level established by law. Act or the Government on the orders of the Act, the Provincial People's Representative Council, the Governor, the Regency/City Regional People's Representative Council, the Regent/Mayor, the Village Head or the equivalent.

These laws and regulations are recognized for their existence and have binding legal force as long as they are ordered by higher laws and regulations or are formed based on authority. If it is associated with the opinion of Hans Kalsen who qualifies law as a legal order is a system of norms, the norm system is a hierarchical arrangement and each norm is sourced from the norms above it, which form it or which provide and determine its validation and become a source for norms. which is below it. At the top of the hierarchy is a basic norm, namely the constitution. These basic norms are the highest basis for the validity of the entire legal system. The constitution referred to here is a constitution in a material sense, therefore in the author's opinion, if it is associated with the position of the Constitutional Court's decision which is final and binding, the position of the Constitutional Court's decision should be part of the hierarchy of laws and regulations and make the Constitutional Court's decision a source of law because it does not there are other legal remedies against the decision, then the decision has become jurisprudence for legislators relating to the substance of the law in the decision of the Constitutional Court.

\section{Review of Decision Number 92/PUU-X/2012}

An example is the decision Number 92/PUU-X/2012 which has restored the authority of the Regional Representatives Council (DPD) which was previously reduced by Law no. 27 of 2009 concerning the MPR, DPR, DPD, and DPRD (MD3) and Law no. 12 of 2011 concerning the Establishment of Legislations (P3). The Constitutional Court's decision clearly states that Article 102 paragraph (1) letters a, d, e, h and Article 147 of the MD3 Law are contrary to the 1945 Constitution and have no binding legal force, meaning that Every bill proposed by the DPD is no longer going through the process in the Legislative Body but is treated as equal to the bill proposed by the President, and will still be considered a bill submitted by the DPD. This decision clearly restores the identity of the DPD as a state institution whose position is equal to the DPR and the President. However, in reality the formation of the Law by the DPR and the Government, namely Law Number 17 of 2014 concerning the People's Consultative Assembly, the People's Representative Council, the Regional Representatives Council and the Regional People's Representative Council did not include the decision of the Constitutional Court Number 92/PUU-X/2012 related to the authority of the DPD as contained in the decision. In connection with the omission of the Constitutional Court's decision Number: 92/PUU$\mathrm{X} / 2012$, we will discuss several very substantive reasons regarding this, including:

\section{a. DPD Functions According to the 1945 Constitution of the Republic of Indonesia}


The Regional Representative Council (DPD) was originally initiated to reorganize the structure of the Indonesian parliament into two chambers (bicameral). Where, the parliament will consist of the House of Representatives (DPR) and the Regional Representatives Council (DPD). The MPR which initially consisted of members of the DPR plus regional representatives and groups, (Article 2 paragraph (1) UUD NRI 1945) was restructured to consist of members of the DPR and members of the DPD. (Article 2 paragraph (1) UUD NRI 1945, Fourth Amendment ). The DPR as a reflection of political representation (political representation) as well as the representation of the local people it represents, while the DPD as a regional or territorial representation (territorial representation). With the reshuffle of the structure of the representative institutions, it is hoped that the legislative process can be carried out based on a double-check system that allows the representation of the interests of the people to be relatively channeled on a broader social basis.

As a result of the changes, the authority of the DPD as regulated in these provisions is considered by many to be not comparable to the legitimacy of the DPD members who are elected through general elections. With very strong legitimacy, the DPD should have an authority comparable to the DPR. In fact, the DPD with all coercion must accept the fact that it has very, very limited authority. In addition, according to the authority as stipulated in Article 22D of the 1945 Constitution, the DPD tends to be associated as a co-legislator whose position is as an auxilary to the legislative function of the DPR. (Article 2 paragraph (1) UUD NRI 1945, Fourth Amendment ) This assessment then underlies the emergence of further provisions that place the legislative function of the DPD no more than that of a member of the DPR. Where, the DPD is only given the authority to submit proposals for draft laws (not draft laws) to the DPR.

Errors in placing the legislative functions of the DPD in Law No. 27 of 2009 and Law No. 12 of 2011 are basically corrected through a process of systematic interpretation of a number of norms in the 1945 Constitution. Systematic or logical interpretation is an interpretation according to the existing system in the legal formulation. alone.( Jimly Asshiddiqie,2010) This interpretation is carried out by taking into account the interrelated provisions in the text of the relevant laws and regulations. This method of interpretation arises because of the assumption that the laws and regulations of a country are a single entity, in the sense that none of these regulations can be interpreted as if they were independent (Yudha Bhakti Ardhiwisastra,2008).

In this interpretation, the steps taken are looking for the meaning of the words contained in a related regulation and also looking at other rules. (Jimly Asshiddiqie,2010) Because, in this interpretation, what must always be remembered is the relationship between statutory regulations or the relationship between norms contained in a law. Systematic interpretation will be able to give rise to two possibilities, namely: first, the occurrence of narrowing of meaning. Second, there is an expansion of the meaning of its meaning in the usual rules of language (Yudha Bhakti Ardhiwisastra,2008).

Specifically for the 1945 Constitution of the Republic of Indonesia, there are a number of provisions that still require interpretation. Because, in its implementation, the provision is actually interpreted differently from the real purpose of the existing constitutional formulation. Among them are provisions related to the formation of laws. In a sense, there is a confusion of understanding regarding the competent institutions and the process that must be carried out in making a law.

In the 1945 Constitution, there are several articles relating to the process of law formation. The articles referred to include: Article 5 paragraph (1), Article 20 paragraph (1) and paragraph (2), Article 21, Article 22D paragraph (1) and paragraph (2). Based on these provisions, there are three state institutions whose duties and authorities are related to the formation of laws, namely the President, DPR and DPD. Meanwhile, regarding the formation process, the 1945 Constitution outlines that there are three general stages of law formation, namely: the stage of submitting a draft law, the stage of discussing the draft law and the stage of making decisions or granting approval.

However, the terms or words used to describe the roles of the three institutions are different at each stage of the formation of the law. So the understanding regarding the involvement of the three institutions is also different. At the submission stage, the term "president has the right" is used for the President. For the DPR, the DPR has the power to form..., while for members of the DPR, "Members of the DPR have the right to nominate.." Meanwhile, for the DPD, the term "DPD can submit..."

At the discussion stage, for the President and the DPR the term "every bill is discussed by the DPR and the President. While for the DPD it is formulated, "DPD will also discuss ...". As for decision making, although it is a separate stage, it is an inseparable part. from the discussion stage. Because Article 20 paragraph (2) states, "...the bill is discussed by the House of Representatives and the President for mutual approval. Based on Article 5 paragraph (1) with the term "President has the right...", meaning that the President has the authority to submit draft laws. In terms, "rights" are defined as possession, possession, authority or power to do something.(Bexar Indonesian Dictionary ( Third Edition), 2005) Thus, the right of the president as referred to in Article 5 paragraph (1) can be interpreted as the authority of the President to submit draft laws to the DPR.

Based on Article 20 paragraph (1), with the term "DPR holds the power...", meaning that the DPR has the right or authority to submit draft laws. In terms, power is defined as the ability, ability or authority to run. (Bexar Indonesian Dictionary ( Third Edition ), 2005) In this case, what is meant is the ability or authority of the DPR in terms of making laws. Article 20 paragraph (1) refers to the institutional powers of the DPR. In a sense, it is the DPR that has the power to form laws institutionally.

Meanwhile, in Article 22D paragraph (1), with the term "DPD may submit ...", it means that DPD may submit draft laws. Because, in terms, the word "can" is equivalent to the word "able, able, can, may, maybe". Where the word is defined as the ability to do something. (Bexar Indonesian Dictionary ( Third Edition ), 2005) Thus, "can submit" means it is permissible or allowed to submit a draft law in accordance with its ability or ability. As long as the DPD is willing to submit a draft law related to its authority, during that time the DPD will also exercise this right institutionally. Thus, the term "can" also means the right to submit a draft law.

This interpretation is also reinforced by the position of the DPD in submitting the draft law. To see where the position of the DPD is at the stage of submitting a draft law, it is necessary to compare the following three formulations:

1. "The president has the right to submit a bill...",

2. "Members of the DPR have the right to submit proposals for draft laws." 


\section{3. "DPD can submit ... draft laws..."}

The material proposed by the President is a draft law. Meanwhile, the material that can be submitted by the DPD is also a draft law. Meanwhile, the material submitted by members of the DPR is the proposed draft law. The draft law is clearly different from the proposed bill. Because a proposed bill cannot be called a draft law until it is approved by the institution that will propose it.

Based on the interpretation of the formulation of Article 5 paragraph (1), Article 21 and Article 22D paragraph (1) above, it is clear that the position of the DPD is equivalent to the President in submitting a draft law. Both are institutions that have the right to submit draft laws, not proposals for draft laws. In addition, the position of the DPD cannot be equated with the position of members of the DPR who are only given the right to submit proposed draft laws. The submission of a draft law to the DPR is in the DPR's capacity as the holder of the power to form laws (Article 20 paragraph (1). However, the power to form laws that belongs to the DPR does not stand alone, but there is a realm of authority for other institutions to give approval). on a draft law.

Therefore, the formulation of Article 22D paragraph (1) which reads, " The Regional Representative Council may submit to the House of Representatives a draft law ..." cannot be used as a basis for classifying or classifying a draft law submitted by the DPD as a draft law. -law "belongs" to the DPR. The DPR cannot claim that the bill proposed by the DPD is a DPR initiative bill. This is because the material submitted by the DPD to the DPR is not a proposed draft law, but a draft law that is final at the DPD institutional level. Therefore, the position of the DPR is not in the capacity to approve the draft law submitted by the DPD to become a draft law belonging to the DPR, but in the position to accept the draft law for discussion in accordance with the provisions of Article 20 paragraph (2) of the 1945 Constitution.

Based on the description above, placing the position of the DPD in the context of submitting a draft law on par with members of the DPR is an unconstitutional act. So that any legal norms that position the DPD as such, are clearly and unequivocally contrary to the 1945 Constitution. for mutual consent". This formulation places the President and the DPR in an equal position and both have the right to discuss draft laws. At the same time, Article 22D paragraph (2) stipulates, "DPD participates in discussing draft laws.". Even if by using the term "participating in the discussion", the DPD in principle also has the right to participate in discussing the draft law. In terms, the word "follow" is understood as "to be with" or to do something as other people do. (Bexar Indonesian Dictionary ( Third Edition ), 2005).

In accordance with this understanding, the word "participation" cannot be interpreted as something that is permissible or not, where participation does not affect. Rather, it is interpreted as the "right" of the DPD to participate in the discussion of the draft law as referred to in Article 22D paragraph (2). In addition, the word "join" also cannot be used as an excuse to subordinate the DPD to the DPR in the discussion of draft laws. This is because the formulation of Article 22D paragraph (2) and Article 20 paragraph (2) are two provisions that are compounded. In a sense, if a draft law is related to regional autonomy, and so on, then Article 20 (2) cannot stand alone. Rather, it must be in conjunction with and compared with Article 22D paragraph (2). Along with that, the discussion of a draft law to become a law in accordance with the provisions of Article 20 paragraph (2) also includes a discussion of the draft law as referred to in Article 22D paragraph (1) and paragraph (2). This means that the draft law related to the region is also part of the draft law that must be discussed and ratified through the mechanism regulated in Article 20 paragraph (2). Thus, Article 22D paragraph (2) which regulates the participation of DPD in the discussion of draft laws cannot be separated from the provisions of Article 20 paragraph (2). In a sense, the participation of DPD in the discussion of the bill is also subject to and refers to the provisions of Article 20 paragraph (2). However, regarding the interpretation of the function of the DPD in the 1945 Constitution of the Republic of Indonesia, it can be accepted by the DPR or not because it is related to the interpretive authority of the 1945 Constitution of the Republic of Indonesia which is not owned by the Constitutional Court.

\section{b. Functions of DPD According to Law no. 12 of 2011 concerning the Hierarchy of Legislation}

Based on Article 65 of Law no. 12 of 2011 concerning the Drafting of Legislations in connection with the function of the DPD in the Discussion of Draft Laws:

1) The discussion of the Draft Law is carried out by the DPR together with the President or the assigned minister.

2) Discussion design The law as referred to in paragraph (1) relating to:

a. regional autonomy;

b. central and regional relations;

c. formation, expansion, and merging of regions;

d. management of natural resources and other economic resources; and

e. central and regional financial balance, carried out by involving the DPD.

3) The participation of DPD in the discussion of the Draft Law as referred to in paragraph (2) is carried out only at level I discussions.

4) DPD's participation in the discussion of the draft Law referred to in paragraph (2) and (3) represented by the fittings in charge of the substance of the Bill - Act discussed.

5) The DPD gives consideration to the DPR on the Draft Law on the State Revenue and Expenditure Budget and the Draft Law relating to taxes, education, and religion.

Article 66 of the UUUP3 explains that the discussion of the Draft Law is carried out through 2 (two) levels of discussion. This can be seen in Article 67 of the UUP3: the two levels of discussion as referred to in Article 66 consist of:

a. level I discussions in commission meetings, joint commission meetings, Legislation Board meetings, Budget Board meetings,

or Special Committee meetings; and

b. level II talks in plenary meetings.

This publication is licensed under Creative Commons Attribution CC BY.

http://dx.doi.org/10.29322/IJSRP.11.12.2021.p12016

www.ijsrp.org 
In relation to the discussion of the Draft Law, the DPD also has a function as stated in Article 68 which states that:1) Level I talks are carried out with the following activities:

a. introduction to deliberation;

b. discussion of problem inventory lists; and

c. mini opinion.

2) In the introduction to the deliberation as referred to in paragraph (1) letter a:

a. The DPR provides an explanation and the President conveys his views if the Draft Law comes from the DPR;

b. The DPR provides an explanation and the President and DPD express their views if the Draft Law relating to the authority of the DPD as referred to in Article 65 paragraph (2) comes from the DPR;

c. The President provides explanations and the factions provide their views if the Draft Law comes from the President; or

d. The President provides an explanation and the factions and the DPD convey their views if the Draft Law relating to the authority of the DPD as referred to in Article 65 paragraph (2) originates from the President.

3) The list of inventory problems as referred to in paragraph (1) letter b shall be submitted by: a. the President if the Draft Law comes from the DPR; or

b. DPR if the Draft Law comes from the President by considering the proposal from the DPD as long as it is related to the authority of the DPD as referred to in Article 65 paragraph (2).

4) Submission of mini opinion as referred to in paragraph (1) letter $\mathrm{c}$ is submitted at the end of level I discussion by: a. fraction;

b. DPD, if the Draft Law relates to the authority of the DPD as referred to in Article 65 paragraph (2); and c. President.

5) In the event that the DPD does not convey the views as referred to in paragraph (2) letter b and letter $d$ and/or does not express the mini opinion as referred to in paragraph (4) letter b, the level I discussion will still be carried out.

6) In level I discussions, leaders of state institutions or other institutions may be invited if the material on the Draft Law relates to state institutions or other institutions.

Level II discussions as referred to in Article 67 letter (b) of the UUP3 are also clearly regulated in Article 69 of the UUP3 which reads:

1) Level II discussions are decision making in plenary meetings with the following activities:

a. submission of reports containing the process, mini-faction opinions, mini-DPD opinions, and results of level I discussions;

b. a verbal statement of approval or rejection from each faction and member requested by the chairman of the plenary meeting; and

c. submission of the President's final opinion by the assigned minister.

2) In the event that the agreement as referred to in paragraph (1) letter b cannot be reached by deliberation to reach a consensus, the decision is made based on the majority vote.

3) In the event that the Draft Law does not obtain mutual approval between the DPR and the President, the Draft Law may not be submitted again in the session of the DPR at that time.

Based on what has been described above, it can be seen that the legislative function of the DPD in the Discussion of Draft Laws is very small compared to the DPR and the President. This is because the DPD was only involved in Phase I to discuss and give considerations related to the Discussion of the Draft Law, where in the decision making (phase II) the DPD was not involved or included in Phase II.

The results of the study underline that there is often a disparity between the reading and implementation stages of the final decision. Thus, after the final decision, the body guarding the constitution should not be in a vacuum without any action. This is because in a number of countries this organ has considerable authority to examine the constitutionality of legislative and executive actions. So, MK-RI should also be given the opportunity to oversee the implementation of its decisions. It is hoped that the Indonesian Constitutional Court in this situation will be able to establish synergistic coordination between the organs whose products are amputated. Without that cooperation and collective spirit, surely the final and binding decision will only become a paper tiger, not implementable and injure efforts to crown the rule of law .

The implementation of the Constitutional Court's decision is the most crucial stage and requires limitations on the actions of state institutions and actors. Thus, the final and binding decision must also be accompanied by a judicial order directed at individuals or state institutions. This is done so that they immediately take constitutional steps. What must be understood, after the final decision of the Constitutional Court-RI may ask the majority of the DPR and the government to revise legal products that have been declared unconstitutional ( corrective revision ).

The revision must be accompanied by a decision and in line with the constitutional choices of the constitutional organs. Here the main problem is; there are no formal provisions governing the implementation of the final decision so that the fundamental aspect of the implementation of the final decision is that the decision must be responded to positively by the DPR and the Government. An objective perspective requires cooperative action between state institutions that seek to harmonize all issues related to the final decision.

Studies in several countries show that the final decision related to the cancellation of tax provisions does not necessarily stop the government's collectibility efforts against taxpayers. In fact, this provision has been amputated from the Taxation Law. This fact should lead us to immediately design an implementable final decision. And I think the character of such a decision is difficult to achieve if the final decision fails to get a positive response from the determinants of the level of state policy. 
However, it should be realized that legal products cannot guarantee our expectations on certain issues. For Satjipto, legal certainty does not fall from the sky. Therefore, legal certainty does not fall at the same time as the birth of the law and its articles and procedures. Above all formality is our own behavior.

Legal certainty requires exertion and strength. So, Satjipto believes that legal certainty is a business. If this is the case, then it would be wrong if we want to achieve the characteristics of a final decision that is implementable by relying solely on the normative acceptability of the dictum of Article 24C paragraph (1) of the 1945 Constitution. Among other things, it only says that the decision of the Constitutional Court of the Republic of Indonesia is final without being accompanied by binding words.

The decision of the Constitutional Court is taken in a Consultative Meeting of Judges (RPH) which is attended by at least 7 (seven) Judges and is read/uttered in a plenary session open to the public which is attended by at least 7 (seven) Judges of the Constitutional Court.

The decision of the Constitutional Court on the petition for judicial review of the 1945 Constitution of the Republic of Indonesia can read as follows:

a. "Declaring the Petitioner's application cannot be accepted", in the event that the application cannot meet the requirements as referred to in Article 56 paragraph (1) of Law Number 24 Year 2003;

b. "Accept the Petitioner's petition", "Declare that the material content of the paragraphs, articles and/or parts of the Law in question is contrary to the 1945 Constitution of the Republic of Indonesia"

"Declare that the content of the paragraphs, articles and/or parts of the Law in question does not have binding legal force", in the case of a reasoned application as referred to in Article 56 paragraph (2), paragraph (3) and Article 57 paragraph (1) of the Law Number 24 of 2003;

c. "Accepted the Petitioner's application", "Stated that the formation of the law in question does not meet the provisions for the establishment of a law based on the 1945 Constitution of the Republic of Indonesia".

"Declaring the Law does not fulfill binding legal force", in the case of a reasoned application as referred to in Article 56 paragraph (4) and Article 57 paragraph (2) of Law Number 24 of 2003;

d. "Declare that the Petitioner's application is rejected", in the event that the Law requested for review does not conflict with the 1945 Constitution of the Republic of Indonesia, both regarding its formation and material.

In reviewing laws, the Constitutional Court in addition to making decisions, also issues provisions in terms of:

1. The petition is not within the authority of the Constitutional Court to adjudicate, whose ruling reads "Declaring that the Constitutional Court is not authorized to hear the petition of the Petitioner"; or

2. The Petitioner withdraws his application, the ruling of which reads "Accept the Petitioner's request to withdraw his application", "Declare the Petitioner's application is withdrawn",

"Ordered the Registrar to record the withdrawal of the Petitioner's application in the Register of Constitutional Cases".

In the event that the decision of the Constitutional Court on the judicial review of the law granting the petition of the Petitioner whose decision states that the content of paragraphs, articles, and/or parts of the law is contrary to the 1945 Constitution of the Republic of Indonesia and has no binding legal force, it shall not means that the Constitutional Court revokes/amends the content of paragraphs, articles, and/or parts of laws or laws as a whole that have been tested because the Constitutional Court does not have the authority to "legislative review" of laws. The authority of the Constitutional Court is only limited to passing a decision stating that the content of paragraphs, articles, and/or parts of the law is contrary to the 1945 Constitution of the Republic of Indonesia and therefore no longer has binding legal force " buiten effect stellen " or " not legally binding ", so that the content of paragraphs, articles, and/or parts of the law is binding as a rule ( rechtsnorm ).

The Constitutional Decisions are forward looking, not backward looking. This means that the law being tested by the Constitutional Court remains in effect, before a decision is made which states that the law in question is contrary to the 1945 Constitution of the Republic of Indonesia and has no binding legal force anymore.

The decision of the Constitutional Court which grants the petition for judicial review of the 1945 Constitution of the Republic of Indonesia is ' declaratoir contitutive', in which the Constitutional Court's decision granting the petition for judicial review can create law

new laws or abolishing existing laws, so that through the decision of the Constitutional Court which grants the petition for judicial review, the Constitutional Justices can create a new law " negative legislator ".

Considering that the Constitutional Court does not have the authority to revoke laws, either partially or in their entirety, and considering the decisions of the Constitutional Court which are " declaratoir ", so that these decisions are obeyed and have binding legal force, in the law it is determined that the decisions of the Constitutional Court must be contained. in the State Gazette of the Republic of Indonesia. If it is included in the State Gazette as part of the product of the judiciary, then in relation to the hierarchy of legal norms as contained in Article 8 of Law Number 12 of 2011 concerning the Order of Legislation, then the Constitutional Court's decision should legally be included as part of the hierarchy. legal norms so as to facilitate the implementation of decisions of the Constitutional Court that have not been revised by the DPR and the President as State institutions with the authority to form laws.

As described earlier, that the Constitutional Court ruling on judicial review of law against the Constitution of the Republic of Indonesia Year 1945 verdict stated granted the petition a legal effect that the substance of the paragraph, chapter, and / or parts of laws that tested the becomes no longer legally binding as a legal norm, because it is contrary to the 1945 Constitution 
of the Republic of Indonesia. Thus, part or all of the provisions of the law become invalid or may not be enforced, so that the law is no longer valid. intact again, because some of the norms do not apply or should not be enforced.

The decision of the Constitutional Court on judicial review has permanent legal force since it has been pronounced/read, so that the implementation of the decision of the Constitutional Court is carried out after the decision is read out. Although the decision of the Constitutional Court has binding legal force since it has been read out, not all decisions of the Constitutional Court that grant the petition of the Petitioner can be directly implemented (executable), because the implementation of the decision of the Constitutional Court still requires a follow-up with the formation of a new law or law. changes, so that when viewed from the implementation of the Constitutional Court's decision on judicial review, the Constitutional Court's decision is divided into 2 (two), namely:

1. Decisions of the Constitutional Court that can be directly implemented are "executable"

2. Decision of the Constitutional Court that requires a follow-up with the formation of a law on amendments to the law in question.

Decisions of the Constitutional Court which are followed up by other regulations (such as Perpu, amendments to the Election Law and KPU Regulations. Against the two decisions of the Constitutional Court, legislators must form a new law, because all of the material is declared to have no binding legal force as law .

In addition to the two Court decisions, there are interesting examples to study, because even though the Constitutional Court's decision does not state in its entirety that the material does not have binding legal force, its follow-up must require a new law. Changes in a legal rule (material content of paragraphs, articles, and/or parts of the law) other than being able to be done through changes to the law in question (revision) or "legislative review", can also be done through a decision of the Constitutional Court on Request for judicial review, both formal and material review ( judicial review). The formal review of the law " formele toetsing recht" is the examination of the law relating to the process or method of forming the law which is deemed by the Petitioner not to meet the provisions under the 1945 Constitution of the Republic of Indonesia, while the material review is "materialeele" . toetsing recht "is a review of laws related to the content of paragraphs, articles, and/or parts of the law which are deemed by the Petitioners to be contrary to the 1945 Constitution of the Republic of Indonesia.

\section{CONCLUSION}

As a negative legislator, the Constitutional Court's decision in judicial review is only in the form of: acceptable (nite onvankelijk verklaraad), granted or rejected, but in fact the Constitutional Court's decision develops decisions in other forms. Decisions in other forms are decisions containing policy arguments and decisions that formulate new legal rules that are final and binding after being pronounced in a trial open to the public and written in the State Gazette. Therefore, the Constitutional Court's decision is part of the norm system (hierarchy of statutory regulations) and in Indonesia, its position is the same as the laws and government regulations and is used as a source of law by the DPR and the Government in forming new laws related to decisions the MK.

\section{REFERENCES}

1. Anan Jamal, Political and Legal Configuration of Judicial Institutionalization Review in Indonesia, Reflection Library, Makasar, 2009. p . 23 .[ In Indonesia]

2. H. Abdul Latief et al, Textbook of Procedural Law of the Constitutional Court i, Total Media, Yogyakarta. 2009, p. 222 .[ In Indonesia]

3. Hans Kalsen, Pure Legal Theory (Fundamentals of Normative Law as Empirical-Descriptive Law, translated by Somardi Linguist, Rimdipress. [In Indonesia]

4. Jimly Asshiddiqie, M. Ali Safa'at, Hans Kalsen's Theory of Law, Secretariat General \& Registrar of the Republic of Indonesia Constitutional Court, Jakarta, 2006. Page 17 .[In Indonesia]

5. Jimly Asshiddiqie, Introduction to Constitutional Law Science, Head of the Press Office, Jakarta, 2010, p. 226. [ In Indonesia]

6. Kartini Kartono in Marzuki, Research Methodology, 1st edition, UII Press, Yogyakarta, p.55

.[In Indonesia]

7. Maruar Siahaan, Procedural Law of the Constitutional Court of the Republic of Indonesia, First Cet, Constitution Press, Jakarta, 2005, p. 206. [ In Indonesia]

8. Decision on Case No. 011-017/PUU-I/2003, dated February 24, 2004, namely the case for judicial review of Law no. 12 of 2003 concerning Elections. [ In Indonesia]

This publication is licensed under Creative Commons Attribution CC BY.

http://dx.doi.org/10.29322/IJSRP.11.12.2021.p12016

WWW.ijsrp.org 
9. Sri Soemantri, Perceptions of the Procedures and Systems of Constitutional Changes in the Body of the Constitution, 1945, Alumni: Bandung, 1987. [In Indonesia]

10. Bexar Indonesian Dictionary ( Third Edition ) Kedaksi Team , Language Center of the Ministry of National Education, Balai Pustaka, Jakarta, 2005, p. 381. [ In Indonesia]

11. Yudha Bhakti Ardhiwisastra, Interpretation and Legal Construction, Alumni Publisher, Bandung 2008, p. 10. [ In Indonesia]

\section{AUTHORS}

First author $\quad$ : Amien Ru'ati : Graduate Student PhD, Study Program: Science Of Law.

Pattimura University, Ambon, Indonesia : Email : amienpasca20@gmail.com

The second author : SEM Nirahua : Faculty Of Law. Pattimura University, Ambon, Indonesia

The third author : J. Tjiptabudy : Faculty Of Law. Pattimura University, Ambon, Indonesia

The fourth author : H. Salmon, : Faculty Of Law. Pattimura University, Ambon, Indonesia 